\title{
On the use of a satellite remote-sensing-based approach for determining aerosol direct radiative effect over land: a case study over China
}

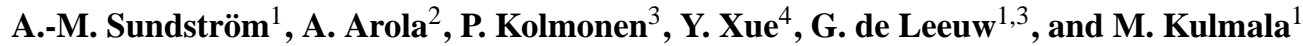 \\ ${ }^{1}$ Department of Physics, University of Helsinki, Helsinki, Finland \\ ${ }^{2}$ Finnish Meteorological Institute, Kuopio, Finland \\ ${ }^{3}$ Finnish Meteorological Institute, Helsinki, Finland \\ ${ }^{4}$ Institute of Remote Sensing and Digital Earth, Chinese Academy of Sciences, Beijing, China
}

Correspondence to: A.-M. Sundström (anu-maija.sundstrom@helsinki.fi)

Received: 28 March 2014 - Published in Atmos. Chem. Phys. Discuss.: 10 June 2014

Revised: 23 September 2014 - Accepted: 2 October 2014 - Published: 15 January 2015

\begin{abstract}
A satellite-based approach to derive the aerosol direct shortwave (SW) radiative effect (ADRE) was studied in an environment with highly variable aerosol conditions over eastern China from March to October 2009. The method is based on using coincident SW top-of-the-atmosphere (TOA) fluxes from the Clouds and the Earth's Radiant Energy System (CERES) and aerosol optical depths (AODs) from the MODerate Resolution Imaging Spectroradiometer (MODIS) to derive SW clear-sky ADRE. The estimate for the aerosolfree TOA flux $\left(F_{0, T O A}\right)$ is obtained by establishing linear regression between CERES SW TOA fluxes and MODIS AODs. A normalization procedure to a fixed solar zenith angle, Earth-Sun distance and atmospheric water vapor content was applied to the CERES fluxes prior to the linear fit against AOD to reduce the flux variation not related to aerosols. In the majority of the cases, the normalization increased positive correlation between observed SW TOA fluxes and AODs, and it decreased RMSE. The key question in the satellite-based approach is the accuracy of the estimated $F_{0 \text {,TOA }}$. Comparison with simulated $F_{0 \text {,TOA }}$ showed that both the satellite method and the model produced qualitatively similar spatial patterns, but absolute values differed. In $58 \%$ of the cases the satellite-based $F_{0, \text { TOA }}$ was within $\pm 10 \mathrm{~W} \mathrm{~m}^{-2}$ of the modeled value (about $7-8 \%$ difference in flux values). Over bright surfaces, the satellite-based method tend to produce lower $F_{0, \text { TOA }}$ than the model. The satellitebased clear-sky estimates for median instantaneous and diurnally averaged ADRE over the study area were $-8.8 \mathrm{~W} \mathrm{~m}^{-2}$
\end{abstract}

and $-5.1 \mathrm{Wm}^{-2}$, respectively. Over heavily industrialized areas, the cooling at TOA was 2 to more than 3 times the median value, and associated with high AODs (>0.5). Especially during the summer months, positive ADREs were observed locally over dark surfaces. This was most probably a method artifact related to systematic change of aerosol type, sub-visual cloud contamination or both.

\section{Introduction}

Aerosols affect the Earth's climate directly by scattering and absorbing solar and infrared radiation, and indirectly by acting as a cloud condensation or ice nuclei and thus modifying the lifetime and radiative properties of clouds. The aerosol direct radiative effect (ADRE) describes the change of energy in the Earth's radiation field due to the scattering and absorption by aerosols. At the top of the atmosphere (TOA), ADRE is defined as the difference between the outgoing shortwave $(\mathrm{SW})$ solar flux without $\left(F_{0, \mathrm{TOA}}\right)$ and with aerosols present $\left(F_{\text {aer,TOA }}\right)$ in the atmosphere. ADRE is considered as the combined radiative effect of anthropogenic and natural aerosols, whereas the aerosol radiative forcing refers to the radiative effect of anthropogenic aerosols only and requires the separation between natural and anthropogenic aerosol components (e.g., Heald et al. (2014)). Negative values of ADRE (or forcing) correspond to increased outgoing radiation and planetary cooling, where as positive values 
correspond to decreased outgoing radiation at TOA and increased atmospheric warming. Several studies conclude that globally the clear-sky ADRE and total forcing are negative (e.g., Haywood and Boucher, 2000; Jacobson , 2001a; Bellouin et al., 2005; Loeb and Manalo-Smith, 2005; Schulz et al., 2006; Quaas et al., 2008; Bellouin et al., 2008; Garcia et al., 2012; Myhre et al., 2013), but the estimates of the magnitude vary. This is mainly due to the large spatial and temporal variation of the aerosol concentration, mass and chemical composition as well as their relatively short lifetime in the atmosphere. Also, different methods and models used to estimate the radiative effect provide different results (IPCC , 2013; Yu et al., 2006). The recent IPCC report (2013) summarizes the estimates of the global direct aerosol radiative effect at TOA for clear sky to range mainly from about -0.1 to $-0.8 \mathrm{~W} \mathrm{~m}^{-2}$, and observation (satellite)-based methods give somewhat more negative estimates than the models (IPCC, 2013). It is noted that locally, the values of the direct aerosol radiative effect can differ significantly from the global estimates (Thomas et al., 2013; Garcia et al., 2012). Positive values of ADRE at TOA can be observed when, e.g., highly absorbing aerosols are transported over bright surfaces such as desert or snow. Also, the direct radiative forcing of some anthropogenic components such as black carbon have been estimated to be positive (e.g., Jacobson , 2001b; Schulz et al., 2006; Myhre et al., 2013).

During the past decade an increasing number of observation-based studies of ADRE and aerosol forcing have been carried out where remote sensing from space plays an important role. For example, Yu et al. (2004), Bellouin et al. (2005) and Yu et al. (2006) showed global estimates of the aerosol radiative effect and forcing by combining remote sensing observations from MODerate Imaging Spectroradiometer (MODIS) and radiative transfer calculations, and more recently Thomas et al. (2013) used the Advanced Along Track Scanning Radiometer (AATSR)-based global aerosol optical depth (AOD) data set GlobAEROSOL with a radiative transfer model. In these studies the remote sensing observations have been used as an input to the radiative transfer model to define the TOA SW fluxes with aerosols. Another remote sensing-based approach to determine the SW ADRE at TOA is to use the AOD from satellite observations with coincident broadband flux observations from instrument such as the Clouds and the Earth's Radiant Energy System (CERES), which provides TOA fluxes in three broadband channels. The advantage is that the outgoing SW flux with aerosols at TOA is directly obtained from CERES measurements, so there is no need to use models to estimate the aerosol properties to infer ADRE (Loeb and Manalo-Smith, 2005). The challenge, on the other hand, is to obtain an estimate for the outgoing SW flux at TOA without aerosols from the measurement data, since aerosols are always present in the atmosphere. The aerosol-free flux is derived by establishing a linear relationship between coincident observations of $\mathrm{SW}$ fluxes and AODs, and then extrapolating to $\mathrm{AOD}=0$. It

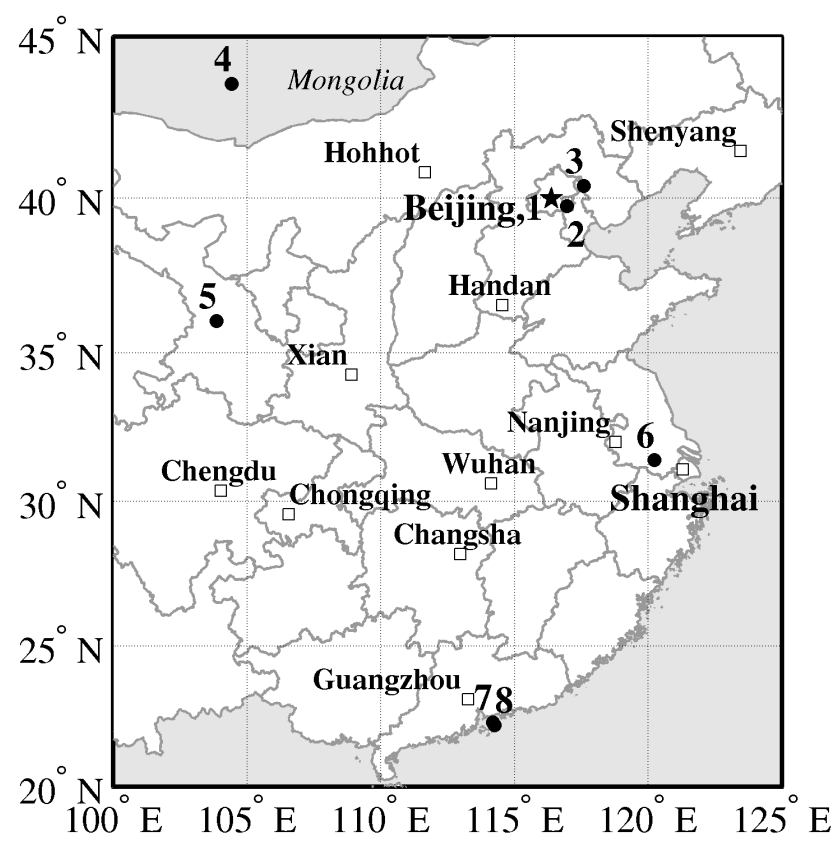

Figure 1. Map of the study area with AERONET stations that provided data during 2009. AERONET stations are 1: Beijing, 2: Xianghe, 3: Xinglong, 4: Dalanzadgad, 5: Lanzhou, 6: Taihu, 7: Hong Kong Polytechnic, and 8: Hong Kong Hok Tsui.

is noted that the resulting ADRE is an instantaneous value, i.e., representative only for the approximate time (and solar zenith angle, SZA) of the satellite overpass. Radiative transfer codes are needed to model the diurnal variation of the SZA, and to expand the obtained satellite observationbased ADRE to represent the $24 \mathrm{~h}$ monthly averages (Remer and Kaufman, 2006) comparable with other estimates of ADRE values presented in the literature. This satellitebased approach has been previously used over the ocean, for example, by Loeb and Manalo-Smith (2005), Zhao et al. (2008) and Christopher (2011), and over land e.g. by Patadia et al. (2008a), Patadia et al. (2008b), Sena et al. (2013), and most recently by Feng and Christopher (2013) (over land and ocean).

The coincident satellite observations of broadband fluxes and AOD provide an unique way to derive an observationbased estimate for ADRE. However, even though this approach has been used in several studies, less attention has been paid to the method itself, which gives the incentive for this study. From a climate and Earth radiative balance point of view the highly variable aerosol conditions over East Asia make the region important and interesting. For this study, a part of eastern China $\left(20-45^{\circ} \mathrm{N}, 110-125^{\circ} \mathrm{E}\right.$, Fig. 1) was selected as the region of interest, hosting one of the fastest growing economies in the world with rapidly expanding anthropogenic activity, industry, urbanization and large-scale agriculture. Along with deriving the ADRE for 8 months from March to October 2009, the key questions 
in this study were focused on the method, e.g., how the satellite-based aerosol-free flux compares to the modeled flux, whether the method works better with a certain aerosol loading or surface, or could some method-related parameter be used to identify possible method artifacts. The initial approach and threshold values were adapted from earlier work of Sena et al. (2013) and Patadia et al. (2008a), with the difference that in this study positive values of the ADRE are also allowed. In the first part of the study a normalization of the CERES TOA fluxes is introduced in order to decrease the noise in flux observations not related to aerosols. In the second part of the study the ADRE is defined, and the aerosol-free flux values obtained from the satellite method are compared to the modeled values. In addition, dependencies between different linear-fitting-related parameters and, e.g., surface albedo are studied. Cases of positive ADRE are also investigated in some detail, and possible reasons for the positive sign (warming) are discussed.

\section{Remote sensing data}

\subsection{CERES SSF data}

The CERES instruments onboard the Earth Observing System (EOS) Terra, Aqua and on Suomi National Polar-orbiting Partnership (NPP) platforms provide radiance measurements in the shortwave $(0.3-5.0 \mu \mathrm{m})$, infrared $(8.0-12.0 \mu \mathrm{m})$ and total $(8.0-200 \mu \mathrm{m})$ broadband channels. The measured radiances are converted to broadband TOA fluxes using angular distribution models (e.g., Loeb and Kato (2002)). In this study data from Terra platform were used, which has the equatorial overpass time of about 10:30 a.m. The CERES Single Scanner Footprint (SSF) Level 2 data set combines the instantaneous daily CERES broadband observations with spatiotemporally coincident aerosol and cloud observations from the higher-resolution imager MODIS on the same satellite platform, and meteorological information provided by the Global Modeling and Assimilation Office (GMAO). The CERES-SSF footprint nadir resolution is about $20 \mathrm{~km}$. The coincident $10 \mathrm{~km}$ MODIS collection 5 aerosol and cloud parameters have been merged into the CERES footprint using point-spread-function-weighted averages. The parameters of the CERES SSF Level 2 files that were used in this work included geolocation (latitude, longitude), upward clear-sky SW TOA flux, AOD at $550 \mathrm{~nm}$, clear-area percent coverage at sub-pixel level and precipitable water. The upward clearsky TOA flux represents the instantaneous value of the reflected SW radiation for clear sky. The clear-area percent coverage at sub-pixel level is based on MODIS $250 \mathrm{~m}$ resolution cloud mask, and it was used as an additional identification of possible sub-footprint clouds as in Sena et al. (2013). All daily observations where the clear-area coverage was less than $99.9 \%$ were removed. The SSF precipitable water is a meteorological model-based parameter that rep- resents the water vapor burden from the surface to TOA (in $\mathrm{cm})$. The study period was March-October 2009.

\subsection{MODIS land data}

The MODIS Land Cover Type Climate Modeling Grid product (MCD12C1) was used to identify inland water bodies within the study area. Based on the data, observations over rivers and lakes were removed from the data set to reduce the surface inhomogeneity within the grid cells. For radiative transfer simulations, monthly means of the SW broadband black-sky albedo were calculated using the MODIS MCD43C3 albedo product. The albedo files contain 16 days of combined level 3 data from Aqua and Terra (e.g., Gao et al., 2005; Zhang et al., 2010). The monthly mean albedo was defined as a weighted average including all the data where the 16-day measurement period overlapped with the month of interest.

\subsection{AERONET data}

AERONET (Aerosol Robotic Network, http://aeronet.gsfc. nasa.gov, Holben et al. (1998)) is a global ground-based monitoring network of aerosol optical, microphysical and radiative properties, providing observations that are available in the public domain. AERONET uses Cimel sunphotometers to measure AOD at 340,380, 440, 500, 675, 870 and $1020 \mathrm{~nm}$, but also provides retrievals of other aerosol parameters, such as the complex refractive index and single scattering albedo (SSA). Figure 1 shows the AERONET stations within the study area that provided data during 2009, and were used in this study. Level 2.0 (cloud-screened and quality-assured) SSA was used in this work to analyze the aerosol types within the region. When level 2.0 data was not available, level 1.5 (cloud-screened) SSA with certain criteria were used: from level 1.5 data, only those observations were included in the analysis where all other quality criteria for level 2.0 were met except the AOD threshold (Arola et al., 2013). The level 2 inversion products are provided only when $\mathrm{AOD} \geq 0.4$.

\section{Simulated a priori estimate of SW ADRE}

The magnitude and sign (cooling/warming) of ADRE at TOA with certain solar zenith angle is a combined result of aerosol type, loading and brightness of the underlying surface. One other factor that determines the magnitude and especially the sign of ADRE at TOA is the position of the aerosol layer relative to the clouds. To get an a priori estimate of what kind of clear-sky ADRE pattern could be expected over the study area, a number of simulations of TOA fluxes were carried out with LibRadtran software (Mayer and Kylling, 2005) using different aerosol types, loadings (AODs) and surfaces. The main part of the LibRadtran software package is the UVSPEC radiative transfer model that allows the calculation 

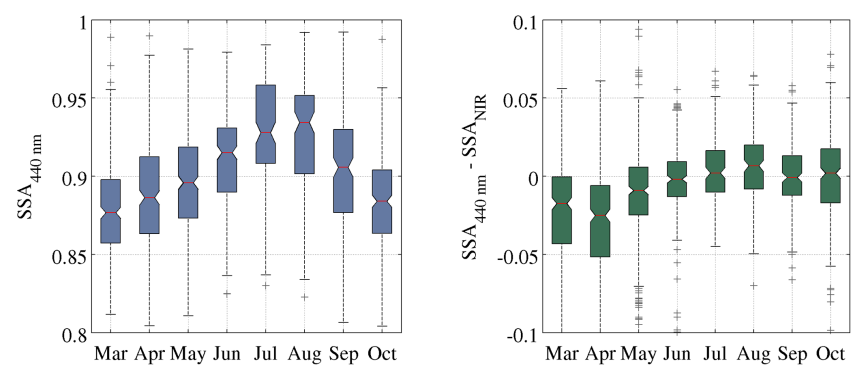

Figure 2. Monthly variation of the SSA at $440 \mathrm{~nm}$ (left) and the difference between SSA at $440 \mathrm{~nm}$ and average of near-infrared channels (NIR, 670, 870, and $1020 \mathrm{~nm}$ ) (right) at the Beijing AERONET station. The red central marks in each box indicate the median values while the upper and lower edges of the boxes indicate 75th and 25 th percentiles. The whiskers are showing extreme values and the outliers are marked with "+".

of the radiation field in the Earth's atmosphere for a variety of atmospheric conditions in the solar and terrestrial part of the spectrum. A unique feature of the UVSPEC is that there are several options for radiative transfer equation solvers. In this work DISORT2 solver was used, and gas absorption was considered by Kato 2 band parametrization.

The aerosol types within the study area were analyzed using SSA from the AERONET stations. Figure 2 shows the monthly variation from March to October of SSA (level 2.0) at $440 \mathrm{~nm}$ and the difference between SSA at $440 \mathrm{~nm}$ and the average of near infrared (NIR; 675, 870, and $1020 \mathrm{~nm}$ ) channels in Beijing AERONET station. During spring, lower SSA and negative difference of the $440 \mathrm{~nm}$ and NIR-channel SSA indicated the presence of dust-type aerosol, whereas high SSA during summer and slightly positive difference between spectral SSA indicated urban-type pollution (Dubovik et al., 2002). Similar but somewhat weaker seasonal variation was observed in Xianghe, Xinglong, and Taihu stations. For Hong Kong and Dalanzadgad stations, level 1.5 data were used because level 2.0 data did not have enough data points for analysis. In Hong Kong, SSA did not have clear seasonal variation, and showed throughout the year similar values to Beijing during summer. In Dalanzadgad, the variation of SSA (level 1.5 data) was relatively large, but the SSA medians indicated slightly more absorbing aerosol type than in other stations. Overall, based on the AERONET data it can be estimated that in the major part of the study area, the SSA (at $440 \mathrm{~nm}$ ) varies mainly around 0.9 , in the southern part mainly around 0.95 and in the remote desert areas in the northwest around 0.85 . Based on these results two aerosol types were selected for the simulations that most likely represent the range of the SSA variation. For weakly absorbing aerosols, the SSA at $500 \mathrm{~nm}$ was 0.97 and for strongly absorbing aerosols 0.8 , respectively (de Leeuw et al., 2013).

The main purpose for simulating the SW ADRE a priori was to identify the areas where the radiative effect is most likely negative and positive. Fig. 3 shows an example for
September 2009 of the monthly mean SW black-sky albedo calculated from the MODIS MCD43C3 albedo product, and simulated SW fluxes at TOA as a function of SW broadband surface albedo with varying AOD for both aerosol types. The simulations were carried out assuming constant solar zenith angle $\left(35^{\circ}\right)$ and water vapor content $(2.0 \mathrm{~cm})$. For both aerosol types a critical albedo can be seen, where the TOA fluxes for increasing AOD are lower than for the aerosolfree case, resulting in positive values of ADRE. For highly scattering aerosols $(\mathrm{SSA}=0.97)$ the critical albedo was about 0.42 , whereas for more absorbing aerosols $(\mathrm{SSA}=0.80)$ the critical albedo was much lower, about 0.14. The MODIS albedo map shows that in major part of the study area, the black-sky SW albedo varied between 0.1 and 0.15 , whereas over the highly populated and industrialized areas, e.g., the one extending from Beijing towards the southwest, the surface was somewhat brighter, with an albedo about 0.17 . Over these areas, negative ADRE is most likely expected, if assuming that the aerosol SSA varies around 0.9. The Gobi in the north and northwest was significantly brighter than other areas (SW albedo $\sim 0.25$ ), which makes the area more susceptible to positive values of ADRE even if the aerosols were not highly absorbing.

\section{Satellite-based method}

\subsection{Deriving the instantaneous SW ADRE}

The instantaneous SW ADRE at the top of the atmosphere for a given location and time is defined as

$$
\begin{aligned}
& \operatorname{ADRE}(\text { lat }, \text { lon, } \theta)=F_{0, \mathrm{TOA}}(\text { lat, lon, } \theta) \\
& -F_{\text {aer,TOA }}(\text { lat, lon, } \theta),
\end{aligned}
$$

where $F_{0, \mathrm{TOA}}$ and $F_{\text {aer,TOA }}$ are the upward shortwave fluxes at TOA without and with aerosols, $\theta$ is the solar zenith angle, lat and lon are the location coordinates. While the CERES flux observations represent the instantaneous values of $F_{\text {aer,TOA, }}$, the estimate for $F_{0, \mathrm{TOA}}$ is obtained by establishing a linear regression between coincident CERES fluxes and MODIS AODs, and extrapolating the regression line to $\mathrm{AOD}=0$. The different steps for defining the satellite-based ADRE are illustrated in Fig. 4. The normalization procedure is described in Sect. 4.2.

In each $0.5^{\circ} \times 0.5^{\circ}$ grid cell the cloud-free flux and AOD observations were collected over 1 month as in, e.g., Patadia et al. (2008b) and Sena et al. (2013). Similarly, to avoid very large pixel sizes, the solar and viewing zenith angles were restricted to less than $60^{\circ}$, and the AOD values were limited to 2.0 to avoid possible nonlinearities that could appear with extreme aerosol loadings. To filter out cloudy or partly cloudy pixels, additional cloud parameters from MODIS were used as explained in Sect. 2.1. For a successful regression it was required that the number of coincident flux AOD observations in a grid cell was at least 10 per month, and that the 
a)

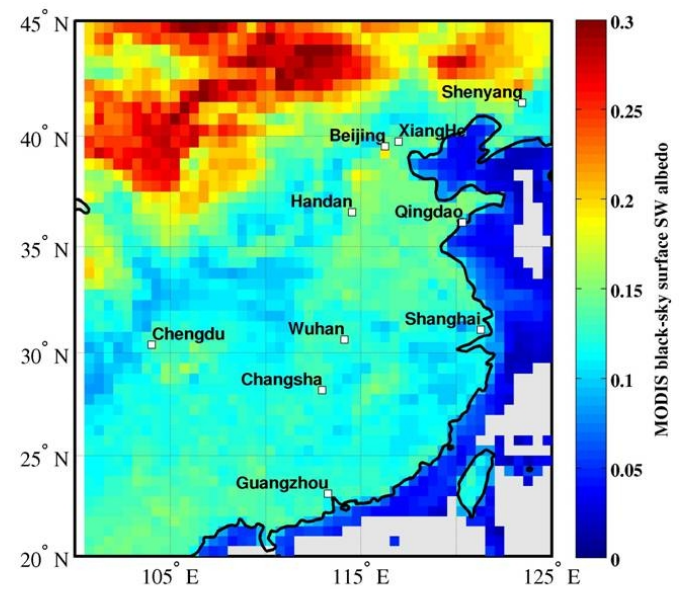

b)

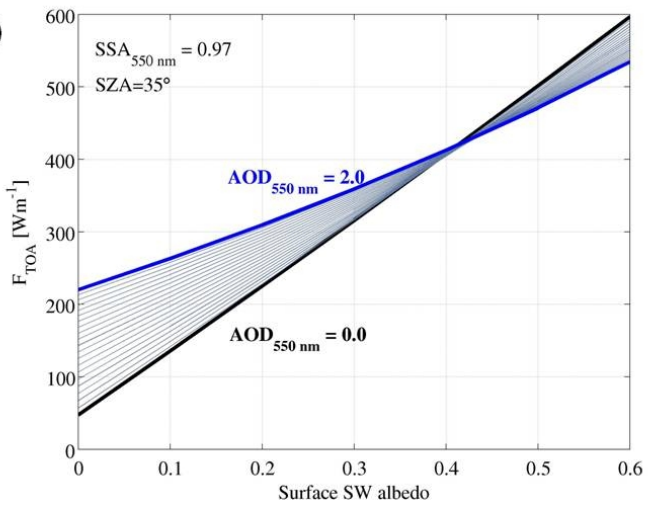

c)

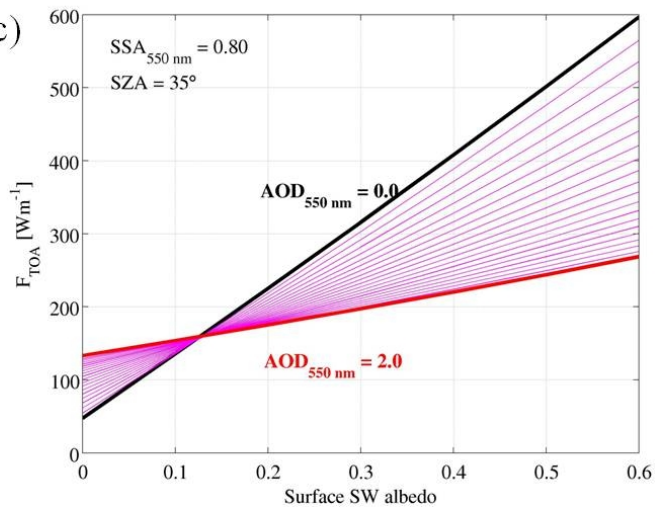

Figure 3. Monthly mean (September 2009) of the shortwave black-sky broadband albedo obtained from the MODIS MCD43C3 data (a), and radiative transfer simulations of TOA SW fluxes as a function of surface albedo and varying aerosol loading for highly scattering (b) and absorbing (c) aerosol type.

absolute value of correlation coefficient $R$ was 0.2 or larger. It is noted that in contrast to Patadia et al. (2008b) and Sena et al. (2013), negative correlations between the AOD and SW TOA fluxes (i.e., positive ADRE) were also allowed in this study. After a successful linear fit, the estimate for $F_{0 \text {,TOA }}$ was obtained and the monthly grid cell value for instantaneous ADRE was defined.

\subsection{Normalization of the CERES SW TOA fluxes}

The essential assumption in the satellite-based method is that the effective aerosol type does not change considerably over a month, and upward SW flux changes at TOA are mainly related to the change in aerosol loading. This assumption does not hold if some aerosol episodes such as biomass burning or dust outbreak occur, but overall the ADRE obtained from fitting should be representative for the monthly mean conditions at the time of the satellite overpass. Furthermore, the observed $F_{\text {aer,TOA }}$ not only depends on aerosols, but is also affected by changes in SZA, surface albedo, atmospheric water vapor content and the day of the year (DOY, i.e., SunEarth distance). The SZA has a seasonal and diurnal variation reaching maximum values at sunrise and sunset, and minimum at noon. ADRE values depend on the SZA so that for larger values of the SZA, the ADRE at TOA becomes more negative. Hence, with large zenith angles cooling is stronger and could be further enhanced with increasing aerosol loading. The amount of atmospheric water vapor is also subject to substantial seasonal variation within the study area. The climate in eastern China is characterized by dry winters and humid, rainy summers. The rainy season starts in May when the monsoon spreads gradually from the southeast onto the Chinese mainland and lasts until about September. With the increasing humidity ADRE at TOA becomes less negative. To account for these variations that are not related to aerosols, and to minimize the noise, the observed CERES fluxes $F_{\text {aer,TOA }}$ were normalized to fixed values of SZA, DOY and water vapor content before establishing the 


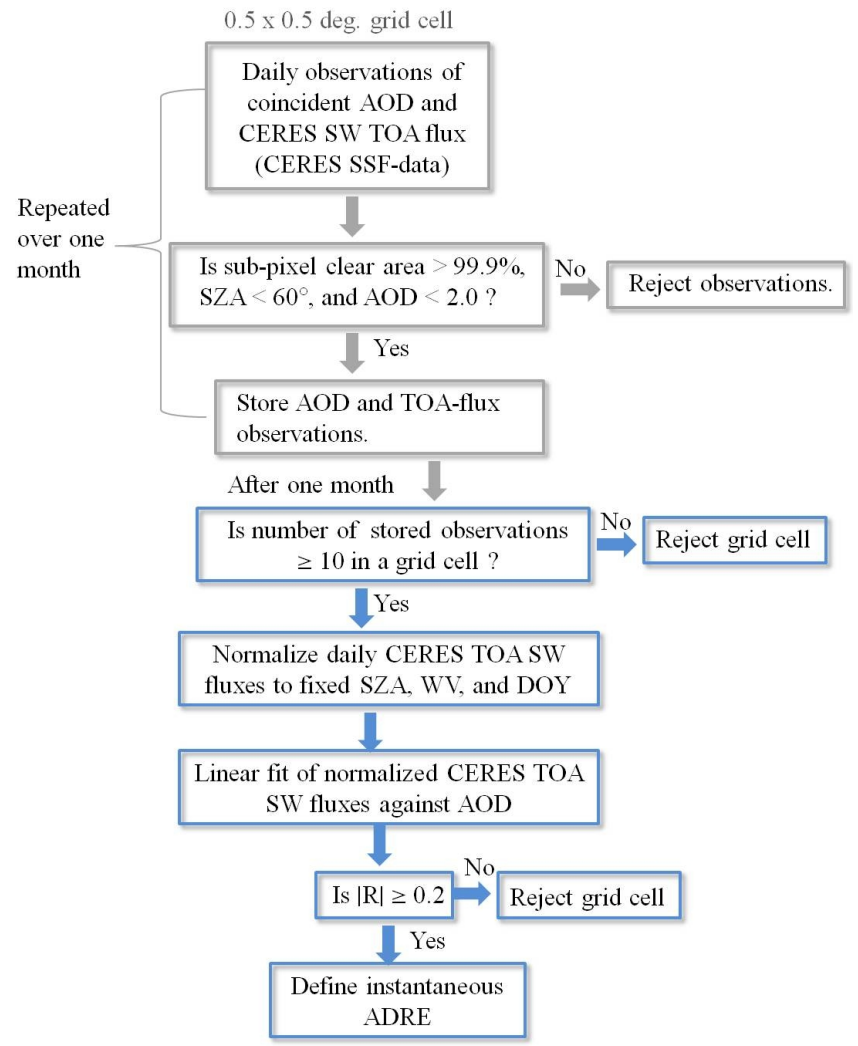

Figure 4. A schematic representation of the satellite-based method for deriving instantaneous SW ADRE at TOA using coincident CERES TOA flux and MODIS AOD observations.

linear fitting against AOD:

$F_{\mathrm{TOA}, \text { norm. }}^{\mathrm{CER}}=F_{\text {aer,TOA }}^{\mathrm{CER}} \times$

$\frac{F_{\mathrm{TOA}}^{\mathrm{mod}}(\text { norm.SZA }) \times F_{\mathrm{TOA}}^{\mathrm{mod}}(\text { norm.WV }) \times F_{\mathrm{TOA}}^{\mathrm{mod}}(\text { norm.DOY })}{F_{\mathrm{TOA}}^{\bmod }(\mathrm{obs} . \mathrm{SZA}, \mathrm{WV}, \mathrm{DOY})^{3}}$,

where the superscript "CER" refers to a CERES observation and "mod" to a modeled TOA flux. The subscript "norm" refers to the fixed values of SZA, water vapor content (WV) and DOY, respectively, to which the observed CERES fluxes are normalized. The fixed values for SZA and water vapor content were the monthly means in each grid cell. The monthly means for these parameters were calculated from the values coincident with the AOD TOA flux observations that were used in the linear fitting. The fixed DOY was the 15th day of the month, and $F_{\mathrm{TOA}}^{\mathrm{mod}}$ (obs.SZA, WV, DOY) was the modeled CERES observation. In each modeled flux the input values for SZA, WV content, DOY, surface albedo and AOD were taken from the CERES SSF file except in those cases when a fixed value was used for one of the three first parameters. In the reference flux simulations scattering aerosol type (single scattering albedo SSA $=0.97$ at $500 \mathrm{~nm}$ ) was assumed. Before deciding the aerosol type used in the simulated reference fluxes, a number of tests with more absorb-
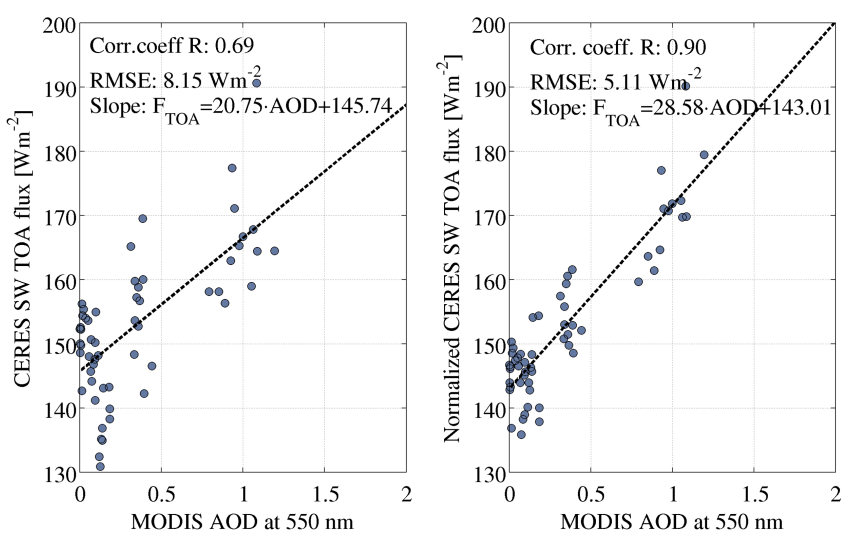

Figure 5. An example of the linear regression between CERES TOA fluxes and MODIS AODs without (left panel) and with (right panel) the normalization of the observed fluxes. This example shows the linear fit for October 2009 in a $0.5 \times 0.5^{\circ}$ grid cell where the Xianghe AERONET station is located. For each month a similar linear fit has been carried out in all of those grid cells where the requirements for a successful regression were met.

ing aerosol types were carried out to evaluate the sensitivity of the normalization procedure to the changing aerosol type. The tests indicated only small differences between the reference flux values associated with more absorbing aerosol types, and the effect on the normalization and linear fitting against AOD was minimal.

When quantifying ADRE, the normalization was carried out in only those grid cells where a successful linear fitting was possible. The normalization according to the surface albedo was not included in this study, and hence the possible variations in surface albedo could still cause scatter in $F_{\mathrm{TOA}, \text { norm. }}^{\mathrm{CER}}$ values. Figure 5 illustrates the effect of the normalization of the CERES fluxes on the linear regression in one grid cell $\left(40.0^{\circ} \mathrm{N}, 117.0^{\circ} \mathrm{E}\right.$, October 2009). Overall, when considering the whole study period, the normalization increased the positive correlation between the CERES fluxes and the MODIS AODs, and decreased the root mean square error (RMSE) in the majority of the cases. It is noted that here RMSE indicates the goodness of fit between CERES flux and MODIS AOD, and thus should not be interpreted as

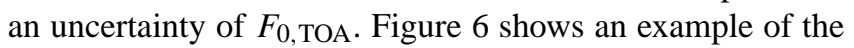
geographical distribution of the correlation coefficient and RMSE anomalies, defined as the difference with and without the TOA flux normalization. The correlation coefficient and RMSE anomalies are shown separately for grid cells where the correlation was initially (without the normalization) positive and negative. As Fig. 6 shows, the positive correlation increased in the majority of the grid cells where $R$ was initially positive. On the other hand, in the cases of initially negative $R$ the correlation coefficient anomaly was overall positive indicating that the negative correlation between AOD and TOA flux became less negative or even changed to pos- 
a)

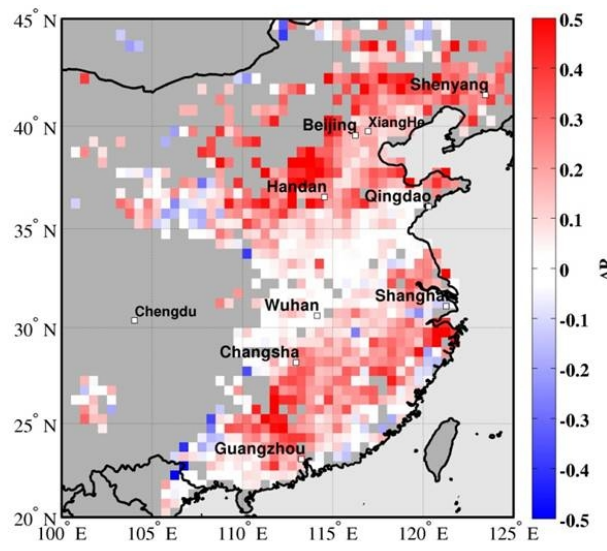

c)

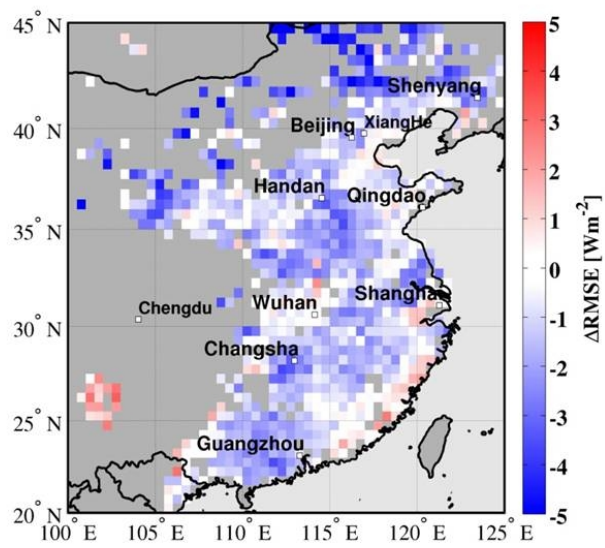

b)

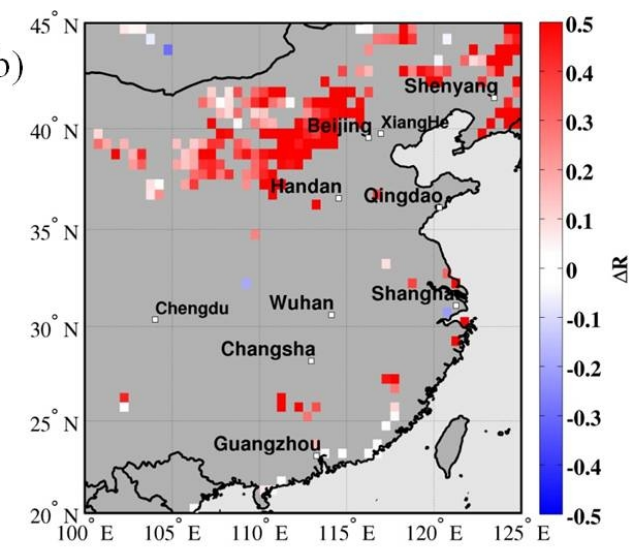

d) $45^{\circ}$

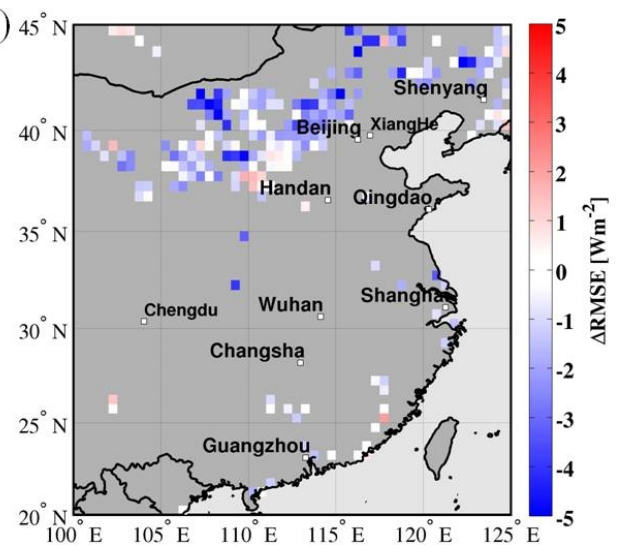

Figure 6. An example of the correlation coefficient (between AOD and CERES TOA fluxes) and RMSE anomalies defined as the difference with and without the normalization procedure. The anomalies are shown for October 2009 separately for grid cells with initially (i.e., without the normalization) positive (a, c) and negative (b, d) correlations.

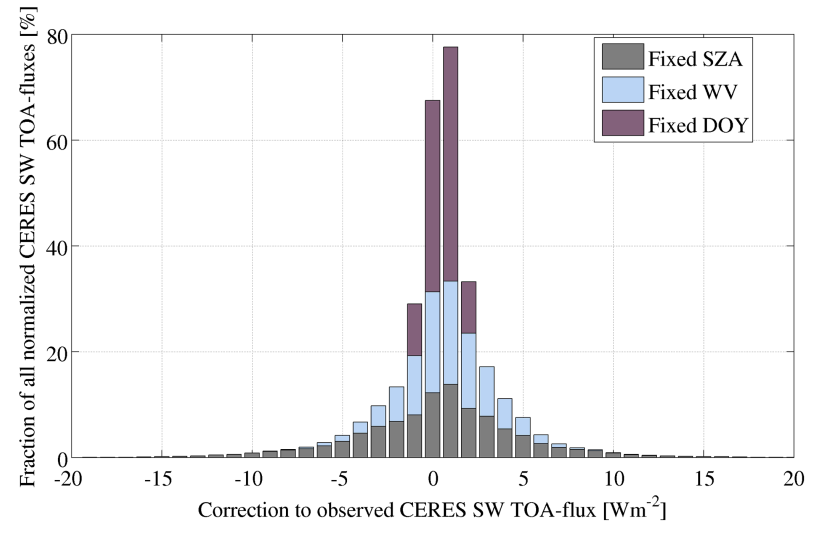

Figure 7. Distribution of the absolute corrections made to the observed CERES fluxes due to the normalization to fixed solar zenith angle, atmospheric water vapor content and day of year. The distribution includes all CERES observations within the study area between March and October 2009 that have been used in the fitting. itive. It is also shown that in the majority of the grid cells RMSE decreased for both cases.

Figure 7 illustrates the number of the normalization corrections made to the observed CERES fluxes. As is seen, the largest corrections in units of $\mathrm{W} \mathrm{m}^{-2}$ are due to the normalization to fixed SZA, which also had a major contribution to the improved correlations between AOD and TOA fluxes. Normalization to the mean water vapor content was important especially during seasons and at locations when the water vapor content had large variation, but overall the distribution of absolute corrections was not as wide as for fixed SZA. The correction of observed fluxes for fixed DOY was mainly between -1.0 and $1.0 \mathrm{~W} \mathrm{~m}^{-2}$.

\subsection{Deriving the diurnal SW ADRE}

The ADRE obtained from the fitting is an instantaneous value, representative for the time of the satellite overpass (SZA), i.e., about 10:30 a.m. (equatorial local time). To estimate the $24 \mathrm{~h}$ mean ADRE and account for the diurnal variation of SZA, the instantaneous ADRE needs to be scaled with the help of modeled ADRE as in Remer and Kaufman 

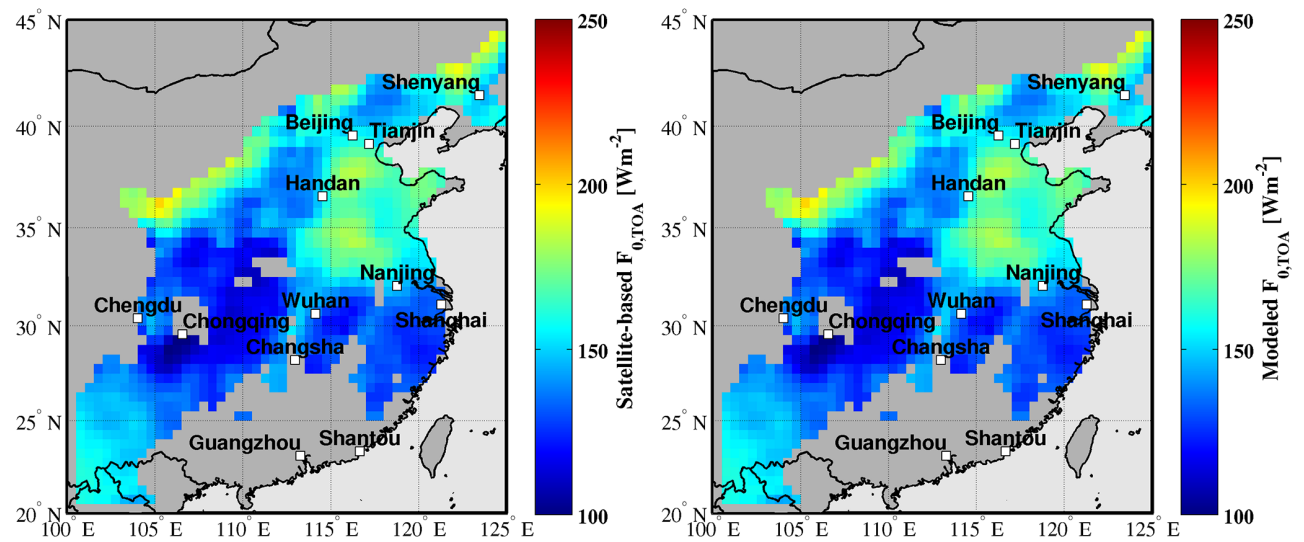

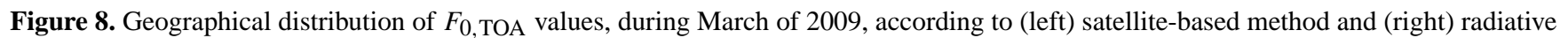
transfer simulations.

(2006):

$$
\begin{aligned}
& \text { ADRE }_{24 \text { h }}^{\text {Sat. }}(\text { lat, AOD, WV }, \alpha) \\
& =\operatorname{ADRE}_{\text {Inst. }}^{\text {Sat. }}(\mathrm{SZA}, \mathrm{AOD}, \mathrm{WV}, \alpha .) \times \\
& \frac{\mathrm{ADRE}_{24 \mathrm{~h}}^{\text {mod }}(\mathrm{lat}, \mathrm{AOD}, \mathrm{WV}, \alpha)}{F_{\text {inst. }}^{\text {mod }}(\mathrm{SZA}, \mathrm{AOD}, \mathrm{WV}, \alpha)}
\end{aligned}
$$

where "mod" refers to modeled fluxes, and " $\alpha$ " to surface albedo. The scaling coefficient for $24 \mathrm{~h}$ ADRE was defined for each grid cell and the diurnal variation of SZA was calculated with $2 \mathrm{~h}$ temporal resolution. Since the diurnal variation of AOD and water vapor are not known, the parameters were assumed to be constant in the model simulations, and in each grid cell the monthly mean values of AOD, water vapor content and surface albedo were calculated from the CERES SSF files. It is expected that the uncertainties related to the diurnal variation of water vapor and AOD are most probably smaller than the other uncertainties related to this satellitebased method (Arola et al., 2013), and thus the assumption of constant AOD and water vapor content is likely to have only a minor effect on the results.

\subsection{Comparison of satellite-based and simulated $F_{0, \text { TOA }}$}

The advantage of the satellite-based approach for defining ADRE is that $F_{\text {aer,TOA }}$ is directly obtained from CERES measurements, and models are not needed to estimate the aerosol or surface properties. Hence to assess the satellite method's ability to produce ADRE, the key question is how

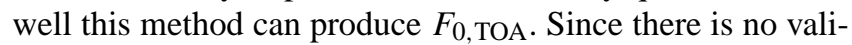
dation (measurement) data for $F_{0, \mathrm{TOA}}$, the LibRadtran radiative transfer model was used to create a data set for a comparison. It is noted that the comparison between the satelliteand model-based $F_{0 \text {,TOA }}$ does not necessarily indicate which method is giving more correct results but it illustrates in which cases the two methods produced similar estimates and

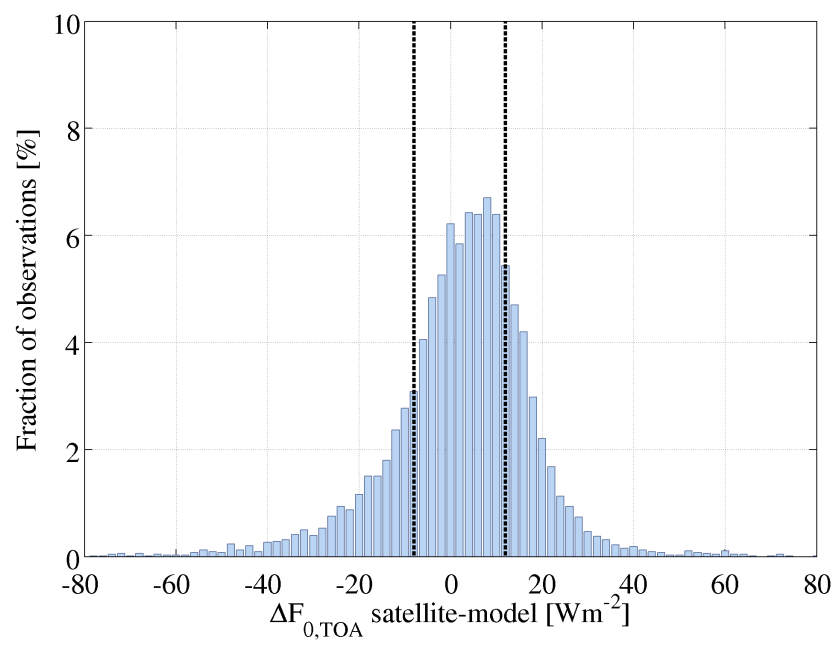

Figure 9. Differences of $F_{0, \text { TOA }}$ obtained from satellite-based fitting method and radiative transfer model simulations including all pixels within the study area from March to October 2009. The black dashed lines indicate $-10 \mathrm{~W} \mathrm{~m}^{-2}$ and $10 \mathrm{~W} \mathrm{~m}^{-2}$ differences.

when not. The $F_{0, \text { TOA }}$ was modeled for each 8 months in the same $0.5 \times 0.5^{\circ}$ grid that was used in the satellite-based method as explained in Sect. 4.1. $F_{0, \mathrm{TOA}}$ was modeled in each month for only those grid cells where the conditions for a successful linear fitting were met. The monthly mean surface albedo was calculated from the MODIS albedo product as explained in Sect. 2.2, whereas the input for SZA and water vapor content were the monthly means calculated from the CERES SSF file using only those observations that were included in the fitting. The DOY was set to the 15 th day of the month.

The results show that the satellite fitting method and the radiative transfer simulations produce a qualitatively similar $F_{0, \text { TOA }}$ spatial pattern. Figure 8 shows an example of $F_{0, \text { TOA }}$ from both methods for March 2009. The satellite- 


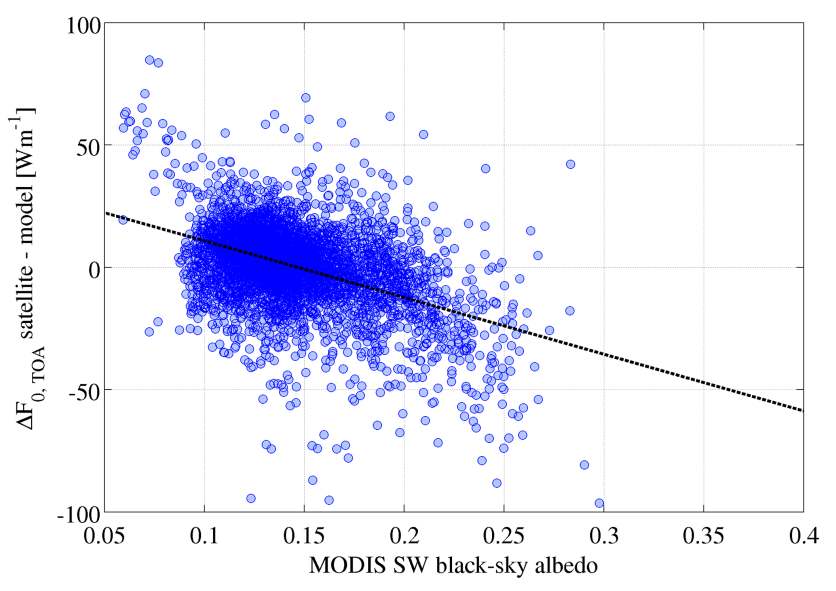

Figure 10. Differences between satellite-based and modeled $F_{0, \text { TOA }}$ as a function of the MODIS black-sky SW albedo.

based approach caught the main features similar to the mod-

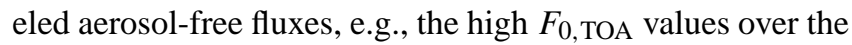
bright areas in the north and northwest as well as the differences in $F_{0, \text { TOA }}$ values over the Beijing and Shanghai areas. The satellite method also showed reasonable seasonal variation of $F_{0 \text {,TOA }}$ with highest values obtained during the summer months. On a pixel level, however, differences in the

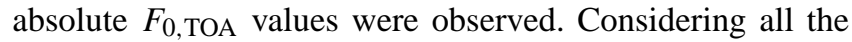
pixels for which ADRE was determined between March and October 2009, in $31 \%$ of the cases the satellite-based method produced $F_{0, \text { TOA }}$ that was within $5 \mathrm{~W} \mathrm{~m}^{-2}$, and in $58 \%$ of cases within $10 \mathrm{~W} \mathrm{~m}^{-2}$ of the modeled values (Fig. 9), which corresponds, on average, with 3-4\% and 7-8\% differences in the $F_{0, \text { TOA }}$ values, respectively. In about $20 \%$ of the cases, the satellite-based $F_{0, \mathrm{TOA}}$ differed more than $10 \mathrm{~W} \mathrm{~m}^{-2}$ from the modeled values. During the summer months, the difference between satellite-based and modeled $F_{0, \mathrm{TOA}}$ was more pronounced.

In most of the grid cells, the satellite-model $F_{0, \text { TOA }}$ difference $\left(\Delta F_{0, T O A}\right)$ changed from positive to negative and vice versa from month to month. There were only a few areas where the satellite-based approach produced systematically lower or higher $F_{0, \text { TOA }}$ than the model. One of the major parameters affecting the CERES flux observations is the surface brightness, and hence the surface albedo could potentially have a large effect on the satellite-based approach for deriving ADRE. Even though the albedo varied considerably (between 0.1 and 0.3 ) within the study area, the albedo values within the $0.5 \times 0.5^{\circ}$ grid cells were typically near uniform. Figure 10 shows $\Delta F_{0, \text { TOA }}$ as a function of MODIS SW black-sky albedo. As the results show, over bright surfaces the satellite-based method tends to produce lower estimate for $F_{0 \text {,TOA }}$ than the model. This might be partly related to very small dynamic AOD range that was often observed over bright desert areas, but it is also noted that MODIS can face challenges in retrieving AOD over bright surfaces (Levy et al., 2010). On the other hand over the mountainous areas to the north and northwest of Beijing the satellite method tend to produce systematically higher $F_{0}$,TOA than the model, which could be related to the varying topography and its effect on TOA flux and AOD observations.

The possible relations between $\Delta F_{0, \mathrm{TOA}}$ and the fittingrelated parameters, such as the correlation coefficient or RMSE, were also studied. Figure 11 shows density plots of $\Delta F_{0, \text { TOA }}$ (satellite-model estimate) as a function of correlation coefficient, RMSE, dynamic AOD range and number of observations obtained in a grid cell in 1 month. With high positive correlation $(R>0.5), \Delta F_{0, \text { TOA }}$ was more likely within $\pm 10 \mathrm{~W} \mathrm{~m}^{-2}$, but large differences could still appear between the two methods, mainly satellite-based $F_{0 \text {,TOA be- }}$ ing lower than the modeled value. Results did not show any clear critical value of correlation which would indicate smaller differences between the satellite-based method and simulations. However, it was found that during the summer months, correlation between the TOA fluxes and AODs were lower than during other seasons, which might explain the pronounced differences of $F_{0, T O A}$ between satellite-based method and model. In addition when the correlation was negative, it seems that in most of the cases the satellite-based method produced larger $F_{0, \text { TOA }}$ than the model. Also, with a broad dynamic AOD range (monthly maximum-minimum AOD) or a high number of observations per month, the count of extreme $\Delta F_{0, \mathrm{TOA}}$ is less. A large dynamic AOD range was most often also associated with high positive correlation between AODs and TOA fluxes, and lower RMSE (not shown). On the other hand, $78 \%$ of the pixels having negative correlation between fluxes and AODs were associated with dynamic AOD range less than 0.4 .

\section{Satellite-based SW ADRE}

The monthly SW ADREs at TOA estimated using the satellite-based method were derived for 8 months from March to October 2009. The best data coverage was obtained during October, when ADRE was successfully derived for $58 \%$ of the land grid cells, but for July ADRE was obtained for only $16 \%$ of the land grid cells, which is mainly due to lack of cloud-free observations during the humid summer months. The seasonal medians of the instantaneous and diurnally averaged ADRE as well as the median AODs in the fitting are shown in Fig. 12. It is noted that the median AODs were calculated only for those grid cells, and from those AOD observations that were included in the linear fitting against CERES fluxes. Hence the seasonal AOD distributions did not, for example, include observations where $A O D \geq 2.0$. The median instantaneous ADRE over the whole measurement period was $-8.8 \mathrm{Wm}^{-2}$, and the $24 \mathrm{~h} \mathrm{ADRE}$ was $-5.1 \mathrm{~W} \mathrm{~m}^{-2}$. The instantaneous and diurnally averaged ADREs were negative over most of the study area, and the strongest cooling at TOA was often associated with large 

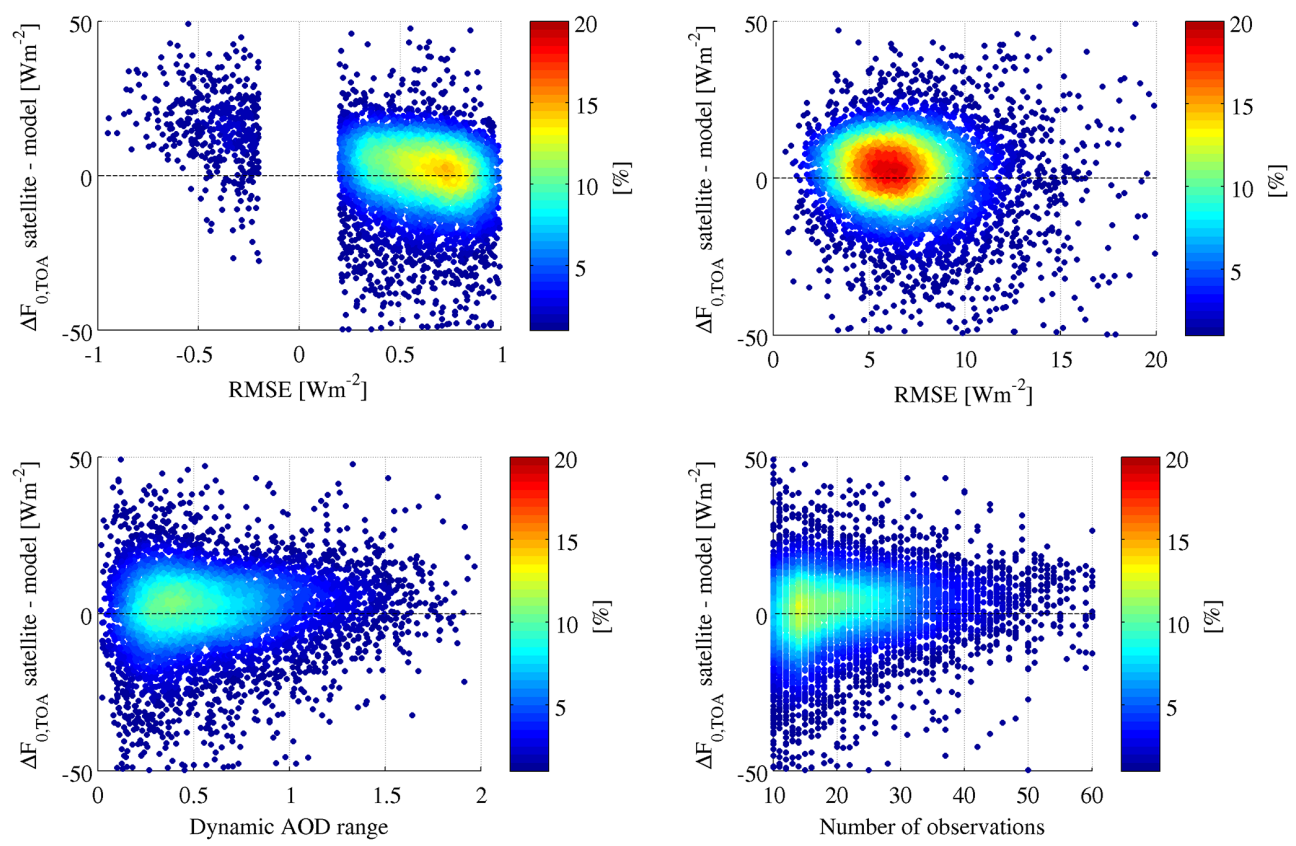

Figure 11. Differences between satellite-based and modeled $F_{0, T O A}$ as a function of (a) correlation coefficient between CERES fluxes and MODIS AODs, (b) RMSE of the linear fitting, (c) dynamic AOD range (the difference between grid cell monthly maximum and minimum AOD values) and (d) number of observations in a grid cell/month. The color scale denotes percent of the observations.

AOD, for example, during spring and autumn over the area extending from south of Tianjin to Handan and further to Chengdu. Another example is Shanghai, where the cooling at TOA was stronger than over the surrounding areas. Figure 13 shows all the instantaneous ADREs derived in this study as a function of AOD, illustrating the connection of aerosol loading and cooling at TOA. However, some exceptions were also found. Some of the highest AODs were observed during spring in the southwestern parts of Wuhan (Fig. 12c), but both the instantaneous and $24 \mathrm{~h}$ ADREs showed less negative or even positive values over that area.

The spatial pattern of the ADRE during the summer was somewhat different than during the two other seasons. The strongest cooling effect was observed over the Jiangsu province north of Shanghai, where the instantaneous ADRE values were twice as negative as during spring or autumn. This was most probably related to crop burning in maize and wheat fields (Huang et al., 2012). On a monthly basis the other notable change during the summer was the more frequent appearance of pixels with positive ADRE, also over areas where the warming effect was not expected. The number of positive ADRE cases increased during May, and then decreased by September. The case of positive ADRE is discussed in more detail in the following section.

\subsection{Cases of positive SW ADRE}

In the case of positive ADRE (i.e., warming at TOA), the correlation between normalized CERES fluxes and MODIS
AODs is negative, i.e., the flux values decrease with increasing AOD. As shown in Sect. 3, positive values of ADRE were mainly expected over the desert, but were unexpectedly observed also over other areas, especially during the summer months. In some of the pixels initially weak positive ADRE changed to negative when the normalization procedure was applied, indicating that the positive effect was an artifact most probably related to variation of SZA or water vapor. However, even after the normalization a number of pixels with positive ADRE still existed over relatively dark surfaces. In fact, only $11 \%$ of the positive ADRE cases were observed over bright surfaces (SW albedo $\geq 0.2$ ). Since detailed information on aerosol types in the study area for specific days and locations was not available, the possibility of extremely absorbing aerosols causing some of the warming effect could not be definitively ruled out. One of the locations with positive ADRE was an area northwest from Shanghai (around $33^{\circ} \mathrm{N}, 116.5^{\circ} \mathrm{E}$ ), in May showing one of the highest negative correlation between the CERES fluxes and MODIS AODs outside the desert area. That area was selected as a test case for more detailed study.

Figure 14 illustrates the linear fitting after the normalization for the $33^{\circ} \mathrm{N}, 116.5^{\circ} \mathrm{E}$ grid cell in May 2009. The correlation coefficient between the normalized CERES fluxes and MODIS AOD was -0.51 , resulting in an instantaneous ADRE of $20.83 \mathrm{~W} \mathrm{~m}^{-2}$. The aerosol-free TOA flux estimate obtained from fitting was $198.2 \mathrm{~W} \mathrm{~m}^{-2}$, which is about $18 \mathrm{~W} \mathrm{~m}^{-2}$ higher than the modeled value for $F_{0 \text {,TOA }}$ for the same grid cell. According to the simulations, a brighter sur- 

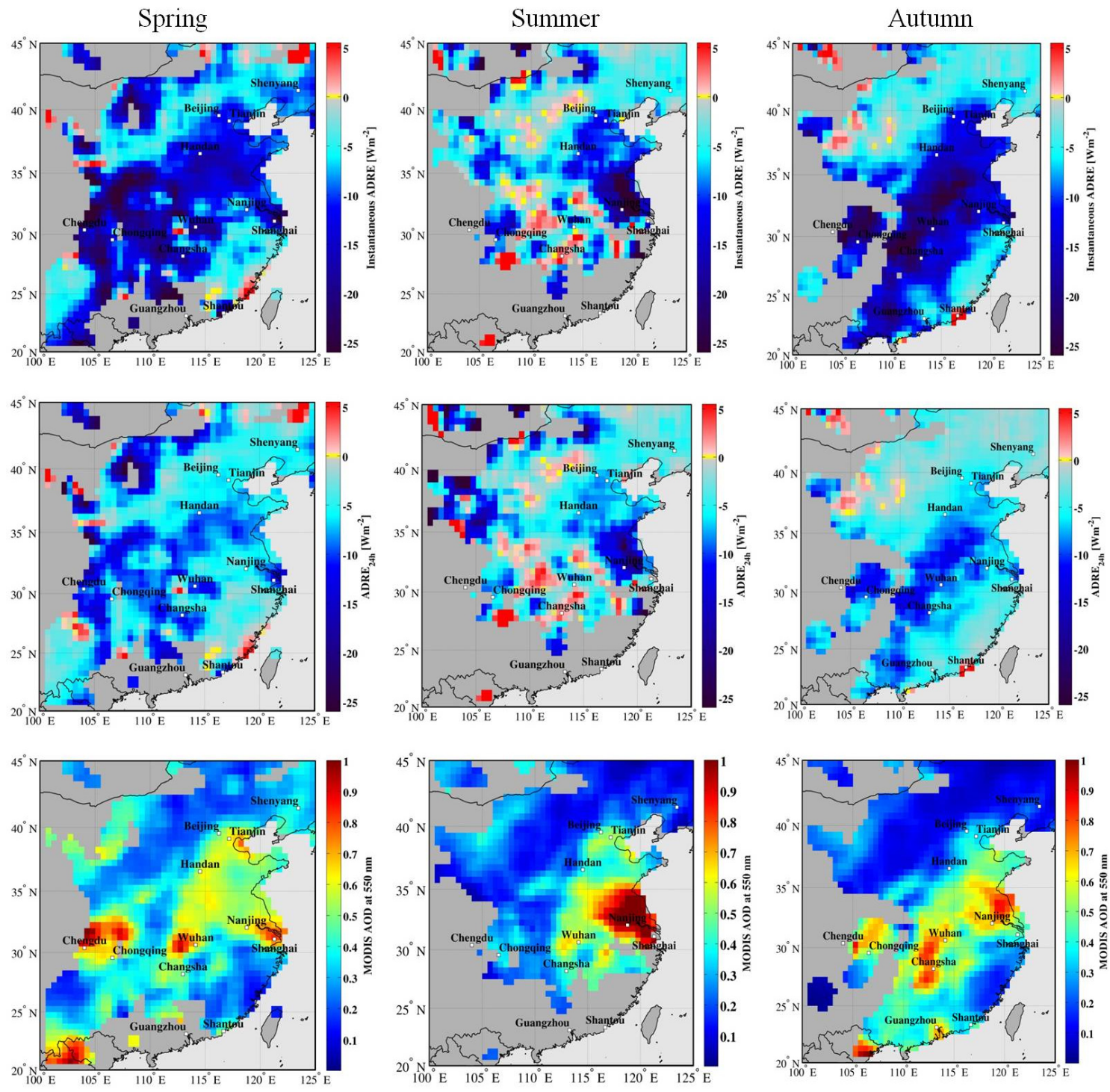

Figure 12. Seasonal geographical distributions of instantaneous (upper row) and $24 \mathrm{~h}$ averaged (middle row) median values as well as the corresponding median AODs (lower row) which have been used in the linear fitting against CERES fluxes. The $24 \mathrm{~h}$ averaged ADRE accounts only for the SZA diurnal variation, whereas other parameters such as AOD and water vapor content were assumed to be constant in the diurnal averaging.

face with an albedo of about 0.175 would be required to produce $F_{0, \text { TOA }}$ similar to the fitting. However, in that grid cell the surface was darker; the broadband SW albedo was about 0.14. In May 2009. the particular grid cell consisted of observations from seven different days having all together 33 coincident TOA flux AOD observations. Figure 14 shows that when AOD was between 0.4 and 0.6, the normalized flux values varied a lot, from values of about $160 \mathrm{~W} \mathrm{~m}^{-2}$ to $195 \mathrm{~W} \mathrm{~m}^{-2}$. For example, on 6 and 7 May the aerosol loading was about the same (AOD 0.43), but the normalized flux values on these days differed by about $20 \mathrm{~W} \mathrm{~m}^{-2}$. One explanation for such a large change in the flux values could be a significant change in aerosol type. According to the radiative transfer simulations, if the AOD would be about 0.4, the SSA should decrease from over 0.95 to about 0.85 to cause such a large difference in TOA flux values. This would imply that the assumption in the method of non-systematic changes in aerosol type was not valid in this case. On the other hand, this could be also related to cirrus contamination, which would mean that both AOD and TOA flux observations were affected. The study by, for example, Sun et al. (2011) showed that globally up to about $50 \%$ of MODIS-derived clear-sky scenes could actually be covered by invisibly thin cirrus clouds. Also, the climatology of all cirrus-type clouds (not only sub-visual) over China by Chen and Liu (2005) shows that the occurrence is highest during summer months. Since 


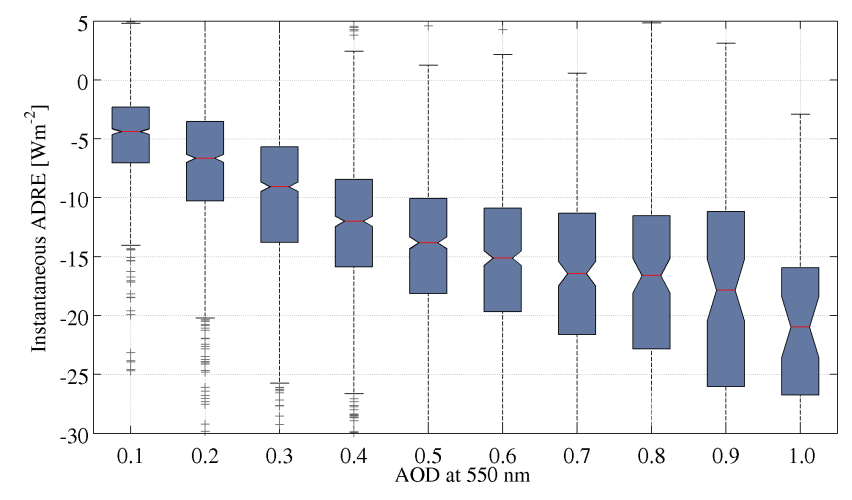

Figure 13. Aerosol direct radiative effect as a function of AOD. The AOD values denote the center of each 0.1 unit bin. Red central marks denote the median values of the ADRE, whereas the upper and lower edges of the box denote the 75th and 25th percentiles. Whiskers show extreme values and outliers are denoted by individual "+" marks.

there are no additional data available about aerosol types or cirrus, either of the possible explanations could be possible. However, the reference simulations of $F_{0 \text {,TOA indicate that }}$ the satellite-based $F_{0, \mathrm{TOA}}$ is too large, and the positive ADRE over the region was most probably a method artifact.

\section{Conclusions}

This study examined a satellite-based approach for determining the aerosol direct radiative effect (ADRE) over eastern China $\left(20-45^{\circ} \mathrm{N}, 100-125^{\circ} \mathrm{E}\right)$ from March to October 2009. In addition to the derived ADRE estimates, the method itself was investigated in detail. As ADRE at TOA is determined as the difference between SW fluxes without and with aerosols, the key challenge of this observation-based method well producing an estimate for the flux without aerosols. Because the aerosol-free flux can not be measured, the satellitebased approach uses coincident observations of SW broadband fluxes from CERES and AODs from MODIS to determine the monthly aerosol-free flux at TOA by establishing a linear regression between the two parameters. It is assumed that the changes in flux values are related to changes in aerosol loading, when the aerosol-free flux can be obtained as the $y$ intercept of the regression line. The satellite-based ADRE estimate is an instantaneous value, representative only at the time of the satellite overpass, about 10:30 a.m. (equatorial local time). Radiative transfer calculations are needed to expand the estimate for diurnally averaged $24 \mathrm{~h}$ ADRE. The approach in this work was similar to that presented in Sena et al. (2013) and Patadia et al. (2008a), with the difference that positive values of ADRE (i.e., negative correlation between TOA fluxes and AOD) were also allowed.

The CERES flux observations not only depend on changes in aerosol loading, but were also affected by the variation of solar zenith angle (SZA), water vapor (WV), Sun-Earth

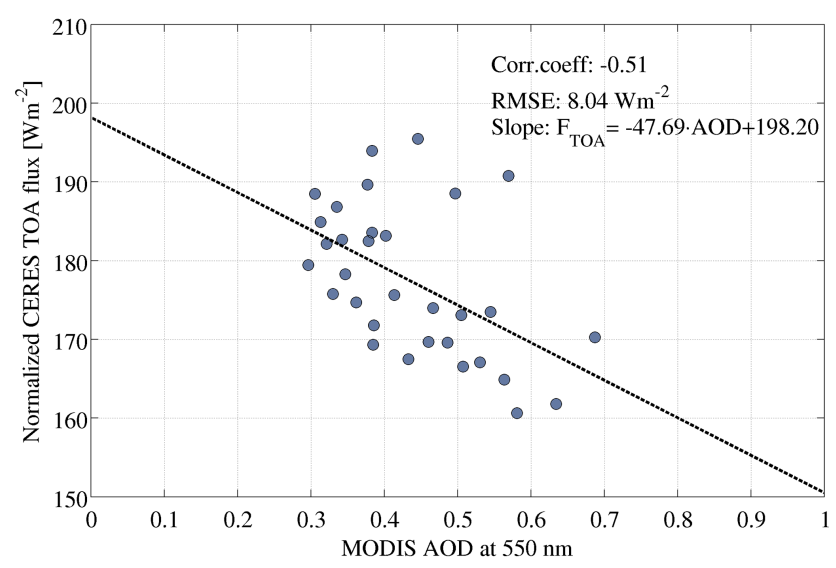

Figure 14. An example of a linear regression that resulted in negative correlation between normalized TOA fluxes and AODs, and hence a warming effect at TOA. In this grid cell $\left(33.0^{\circ} \mathrm{N}, 116.5^{\circ} \mathrm{E}\right)$ the MODIS black-sky SW albedo was 0.14. Due to the relatively dark surface, a warming effect was not expected over this area.

distance (DOY) and surface albedo. Since the linear regression was performed using coincident observations from 1 month, the variation of these parameters also caused noise in the observed CERES fluxes. In this work a normalization procedure to fixed SZA, WV and DOY to the CERES fluxes was applied before the actual linear fitting. The results show that the normalization decreased the non-aerosol induced noise in the flux observations, and in the majority of the cases increased the positive correlation with AOD and decreased RMSE. In some cases, the normalization also changed ADRE from weakly positive to negative, and hence possibly removed some method artifacts.

One of the key questions in this study was how well the satellite method produced the aerosol-free flux. For comparison, the aerosol-free fluxes for each month were also modeled using the LibRadtran radiative transfer code and MODIS broadband albedos. Results show that both methods produced qualitatively similar spatial patterns of $F_{0}$,TOA, but the absolute values differed somewhat. In $58 \%$ of all cases the $F_{0, \text { TOA }}$ difference between the satellite method and the model was within $\pm 10 \mathrm{~W} \mathrm{~m}^{-2}$. Extreme differences were often associated with low dynamic AOD range $(<0.4)$ and/or grid cells with less than 20 observations per month. The results also showed that over bright surfaces, the satellite-based method tended to produce lower $F_{0, \text { TOA }}$ than the model.

As expected, the ADRE over the study area was overall negative, and the strong cooling at TOA was often associated with high AOD. The instantaneous median ADRE of the study area was $-8.8 \mathrm{Wm}^{-2}$, and the diurnally averaged ADRE was $-5.1 \mathrm{~W} \mathrm{~m}^{-2}$, but locally a large variation around these medians were observed. Over heavily industrialized and populated areas, the ADRE could be more than 3 times the median values, which indicated that within the study area the anthropogenic aerosol emissions have large contribution 
to the cooling of the atmosphere. The obtained satellite-based ADRE estimates are in line with values found in other studies using different methods (e.g., Thomas et al., 2013). Locally some positive ADREs, especially during the summer months, were observed outside desert areas where the surface is darker, and the aerosols should have been strongly absorbing to produce a warming effect at TOA. In fact, $78 \%$ of all positive ADRE cases were observed over darker surfaces than desert. The majority of these cases were most probably method artifacts related to some systematic change in aerosol type, sub-visual cloud contamination or both. In some locations this conclusion was also supported by the high values of satellite-based $F_{0 \text {,TOA. However, on the whole, the pixels }}$ with positive ADREs were different, and some additional in situ data, e.g., aerosol single scattering albedos would have been needed to define case by case whether the warming effect was real or not.

The satellite-based approach for determining ADRE offers a valuable observation-based comparison for the model simulated estimates of aerosol direct radiative effects. This study shows that this method can be applied over areas with large variations in aerosol load and surface properties, but attention should be paid especially to cases of positive ADRE. Over bright surfaces, positive ADRE at TOA is physically justified, but over darker surfaces strongly absorbing aerosols are required to produce warming at TOA. One good indication of a method artifact, which also applies in cases of negative ADRE, could be the satellite-based value of $F_{0, T O A}$. Comparison of satellite-based $F_{0, \mathrm{TOA}}$ to, for example, simulated thresholds of $F_{0 \text {,TOA }}$ could help to identify the apparent artifact cases.

Acknowledgements. This work has been supported by the Academy of Finland Centres of Excellence program (project no. 272041), Marco Polo (EU FP7 SPACE Grant, agreement no. 606953), MEGAPOLI (EU FP7 FP7-ENV-2007.1.1.2.1), EUCAARI (EU FP6, contract no. 036833-2), and Aerosol-cci (ESA-ESRIN project AO/1-6207/09/I-LG). The CERES SSF-data was obtained from the Atmospheric Science Data Center at the NASA Langley Research Center, and the MODIS surface data products were obtained through the online data pool at the NASA Land Processes Distributed Active Archive Center (LP DAAC).

Edited by: S. Kazadzis

\section{References}

Arola, A., Eck, T. F., Huttunen, J., Lehtinen, K. E. J., Lindfors, A. V. and Myhre, G, Smirnov, A., Tripathi, S. N. and Yu, H.: Influence of observed diurnal cycles of aerosol optical depth on aerosol direct radiative effect, Atmos. Chem. Phys., 13, 78957901 doi:10.5194/acp-13-7895-2013, 2013.

Bellouin N., Jones A., Haywood, J., and Christopher S. A.: Updated estimate of aerosol direct radiative forcing from satellite observa- tions and comparison against the Hadley Centre climate model, J. Geophys. Res., 113, D10205,doi:10.1029/2007JD009385, 2008.

Bellouin, N., Boucher, O., Haywood, J., and Reddy, M.: Global estimate of aerosol direct radiative forcing from satellite measurements, Nature, 438, 1138-1141, 2005.

Chen, B. and Liu, X.: Seasonal migration of cirrus clouds over the Asian Monsoon regions and the Tibetan Plateau measured from MODIS/Terra, Geophys. Res. Lett.,32, L01804, doi:10.1029/2004GL020868, 2005.

Christopher, S. A.: Satellite remote sensing methods for estimating clear sky shortwave Top of atmosphere fluxes used for aerosol studies over the global oceans, Remote Sens. Environ., 115, 3002-3006, 2011.

de Leeuw, G., Holzer-Popp, Bevane, S., Daviese, W. H., Descloitres, J., Graingerg, R. G., Griesfellerh, J., Heckel, A., Kinne, S., Klüser, L., Kolmonen, P., Litvinov, P., Martynenko, D., North, P., Ovigneur, B., Pascal, N., Poulsen, C., Ramon, D., Schulz, M., Siddans, R., Sogacheva, L., Tanre, D., Thomas, G. E., Virtanen, T. H., von Hoyningen-Hüne, W., Vountas, M., and Pinnock, S.: Evaluation of seven European aerosol optical depth retrieval algorithms for climate analysis, Remote Sens. Environ., doi:10.1016/j.rse.2013.04.023, in press, 2013.

Dubovik, O., Holben, B., Eck, T. F., Smirnov, A., Y. J., K., King, M. D., Tanré, D., and Slutsker, I.: Variability of Absorption and Optical Properties of Key Aerosol Types Observed in Worldwide Locations, J. Atmos. Sci., 59, 590-608, 2002.

Feng, N. and Christopher, S.: Satellite and surface-based remote sensing of Southeast Asian aerosols and their radiative effects, Atmos. Res., 122, 544-554, 2013.

Gao, F., Schaaf, C., Strahler, A., Roesch, A., Lucht, W., and Dickinson, R.: MODIS bidirectional reflectance distribution function and albedo Climate Modeling Grid products and the variability of albedo for major global vegetation types, J. Geophys. Res., $110,2005$.

Garcia, O. E., Diaz, J. P., Exposito, F. J., Diaz, A. M., Dubovik, O, Derimian, Y., Dubuisson, P., and Roger J.-C.: Shortwave radiative forcing and efficiency of key aerosol types using AERONET data, Atmos. Chem. Phys., 12, 5129-5145, doi:10.5194/acp-125129-2012, 2012.

Haywood, J. and Boucher, O.: Estimated of the direct and indirect radiative forcing due to Tropospheric aerosols: A review, Rev. Geophys., 38, 4, 513-543, 2000.

Heald, C. L., Ridley, D. A., Kroll, J. H., Barrett, S. R. H., CadyPereira, K. E., Alvarado, M. J., and Holmes, C. D.: Contrasting the direct radiative effect and direct radiative forcing of aerosols, Atmos. Chem. Phys., 14, 5513-5527, doi:10.5194/acp-14-55132014, 2014.

Holben, B., Eck, T. F., Slutsker, I., Tanre, D., Buis, J. P., Setzer, A., Vermote, E., Reagan, J. A., Kaufman, Y. J., Nakajima, T., Lavenu, F., Jankowiak, I., and Smirnov, A.: AERONET - A Federated Instrument Network and Data Archive for Aerosol Characterization, Remote Sens. Environ., 66, 1-16, 1998.

Huang, X., Li, M., Li, J., and Song, Y.: A high-resolution emission inventory of crop burning in fields in China based on MODIS Thermal Anomalies/Fire products, Atm. Environ., 50, 9-15, 2012.

IPCC: Fifth Assessment Report: Climate Change 2013, Cambridge University Press, New York, NY, USA, 2013. 
Jacobson, M. Z.: Global direct radiative forcing due to multicomponent anthropogenic and natural aerosols, J. Geophys. Res., 106, D2, 1551-1568, 2001a.

Jacobson, M. Z.: Strong radiative heating due to the mixing state of black carbon in atmospheric aerosols, Nature, 409, 695697,doi:10.1038/35055518, 2001b.

Levy, R., Remer, L. A., Kleidman, R. G., Mattoo, S., Ichoku, C., Kahn, R., and Eck, T. F.: Global evaluation of the Collection 5 MODIS dark-target aerosol products over land, Atmos. Chem. Phys., 10, 10399-10420, doi:10.5194/acp-10-10399-2010, 2010.

Loeb, N. G. and Kato, S.: Top-of-Atmosphere Direct Radiative Effect of Aerosols over the Tropical Oceans from the Clouds and the Earth's Radiant Energy System (CERES) Satellite Instrument, J. Climate, 15, 1474-1484, 2002.

Loeb, N. G. and Manalo-Smith, N.: Top-of-Atmosphere Direct Radiative Effect of Aerosols over Global Oceans from Merged CERES and MODIS Observations, J. Climate, 18, 3506-3526, 2005.

Mayer, B., and Kylling, A.: Technical note: The libRadtran software package for radiative transfer calculations - description and examples of use, Atmos. Chem. Phys., 5, 1855-1877, doi:10.5194/acp-5-1855-2005, 2005.

Myhre, G., Samset, B. H., Schulz, M., Balkanski, Y., Bauer, S., Berntsen, T. K., Bian, H., Bellouin, N., Chin, M., Diehl, T., Easter, R. C., Feichter, J., Ghan, S. J., Hauglustaine, D., Iversen, T., Kinne, S., Kirkevåg, A. , Lamarque, J.-F., Lin, G., Liu, X., Lund, M. T., Luo, G., Ma, X., van Noije, T., Penner, J. E., Rasch, P. J., Ruiz, A., Seland, Ø., Skeie, R. B. , Stier, P., Takemura, T., Tsigaridis, K., Wang, P., Wang, Z., Xu, L., Yu, H., Yu, F., Yoon, J.-H., Zhang, K., Zhang, H., and Zhou, C.: Radiative forcing of the direct aerosol effect from AeroCom Phase II simulations, Atmos. Chem. Phys., 13, 1853-1877, doi:10.5194/acp-13-18532013, 2013.

Patadia, F., Gupta, P., and Christopher, S. A.: First observational estimates of global clear sky shortwave aerosol direct radiative effect over land, Geophys. Res. Lett., 35, doi:10.1029/2008JD010754, 2008a.

Patadia, F., Gupta, P., Christopher, S. A., and Reid, J. S.: A Multisensor satellite-based assessment of biomass burning aerosol radiative impact over Amazonia, J. Geophys. Res., 113, doi:10.1029/2007JD009486, 2008b.

Quaas, J., Boucher, O., Belloiun, N., and Kinne, S.: Satellite-based estimate of the direct and indirect aerosol climate forcing, J. Geophys. Res.,113, D05204,doi:10.1029/2007JD008962, 2008.
Remer, L. and Kaufman, Y. J.: Aerosol direct radiative effect at the top of the atmosphere over cloud free ocean derived from four years of MODIS data, Atmos. Chem. Phys., 6, 237-253, doi:10.5194/acp-6-237-2006, 2006.

Schulz, M., Textor, C., Kinne, S., Balkanski, Y., Bauer, S., Berntsen, T. , Berglen, T., Boucher, O., Dentener, F., Guibert, S., Isaksen, I. S. A., Iversen, T., Koch, D., Kirkevåg, A., Liu, X., Montanaro, V., Myhre, G., Penner, J. E., Pitari, G., Reddy, S., Seland, $\emptyset$., Stier, P., and Takemura, T.:Radiative forcing by aerosols as derived from the AeroCom present-day and pre-industrial simulations, Atmos. Chem. Phys., 6, 5225-5246, doi:10.5194/acp-65225-2006, 2006.

Sena, E. T., Artaxo, P., and Correia, A. L.: Spatial variability of the direct radiative forcing of biomass burning aerosols and the effects of land use change in Amazonia, Atmos. Chem. Phys., 13, 1261-1275, doi:10.5194/acp-13-1261-2013, 2013.

Sun, W., Videen, G., Kato, S., Lin, B., Lukashin, C., and Hu, Y.: A study of subvisual clouds and their radiation effect with a synergy of CERES, MODIS, CALIPSO, and AIRS data, J. Geophys. Res., 116, D22207, doi:10.1029/2011JD016422, 2011.

Thomas, G. E., Chalmers, N., Harris, B., Grainger, R. G., and Highwood, E. J.: Regional and monthly and clear-sky aerosol direct radiative effect (and forcing) derived from the GlobAEROSOLAATSR satellite aerosol product, Atmos. Chem. Phys., 13, 393410, doi:10.5194/acp-13-393-2013, 2013.

Yu, H., Dickinson, R. E., Chin, M., Kaufman, Y., Zhou, M., Zhou, L., Tian, Y., Dubovik, O., and Holben, B. N.: Direct radiative effect of aerosols as determined from a combination of MODIS retrievals and GOCART simulations, J. Geophys. Res., 109, 2004.

Yu, H., Kaufman, Y. J., Chin, M., Feingold, G., Remer, L. A., Anderson, T. L., Balkanski, Y., Bellouin, N., Boucher, O., Christopher, S., DeCola, P., Kahn, R., Koch, D., Loeb, N., Reddy, M. S., Schulz, M., Takemura, T., and Zhou, M.: A review of measurement-based assessments of the aerosol direct radiative effect and forcing, Atmos. Chem. Phys., 6, 613-666, doi:10.5194/acp-6-613-2006, 2006.

Zhang, X., Liang, S., Wang, K., Li, L., and Gui, S.: Analysis of Global Land Surface Shortwave Broadband Albedo From Multiple Data Sources, IEEE J-STARS, 3, 296-305, doi:10.1109/JSTARS.2010.2049342, 2010.

Zhao, T. X.-P., Yu, H., Lazlo, I., Zhin, M., and Conant, W.: Derivation of component aerosol direct radiative forcing at the top of atmosphere for clear-sky oceans, J. Quant. Spectrosc. Radiat. Transfer, 109, 1162-1186, 2008. 